\title{
THE EFFECTS OF PERCEIVED RISK ON SOCIAL COMMERCE ADOPTION BASED ON THE TAM MODEL
}

\author{
Saba Torki Biucky \\ Department of Social Science and Economics, Alzahra University, \\ saba.biucky@gmail.com \\ Neda Abdolvand \\ Department of Social Science and Economics, Alzahra University, \\ n.abdolvand@alzahra.ac.ir (Corresponding Author) \\ Saeedeh Rajaee Harandi \\ Department of Social Science and Economics, Alzahra University, \\ saeedeh.rh@gmail.com
}

\begin{abstract}
With the emergence of electronic commerce, the development of social networks has introduced the concept of social commerce. Since accepting new technology can be somewhat challenging for Internet users, this study examines the effect of perceived risk on the adoption of social commerce from their perspective. For this purpose, a conceptual model based on the Technology Acceptance Model (TAM) has been created to take into account different types of risks, including financial, functional, social, time, psychological, and privacy risks. The results of the study, which applied a structural equation modelling (SEM) approach and partial least squares (PLS), revealed that, among 277 active users of social media, perceived risk has a significant impact on the perceived usefulness of social commerce. Moreover, among the different constructs of risk, psychological and social risks have no noticeable effect on commerce adoption.
\end{abstract}

Keywords: Social Networking, E-Commerce, Social Commerce, TAM, Perceived Risk

\section{INTRODUCTION}

The rapid advances in technology have led to the development of business markets and, in turn, have brought about accelerated changes in 
traditional marketing. Today, online advertising and marketing, the methods and techniques of online product sales, commercial interactions and business information exchanges, and online auctions are widely used methods of commerce, so business owners cannot survive by relying on their previous practices.

With the advent of social media, the customer-relationship environment has changed, and vendors are forced to address their customers' changing needs. ${ }^{1}$ Business owners and marketing managers attempt to use actual customers to influence potential customers and encourage them to buy products. ${ }^{2}$ They also provide suitable products by analyzing the information gathered in these networks and analyze the relationships between customers and businesses and the similarities between their behaviors.

As the exchange of ideas about products on social networks provides better and cheaper opportunities to gather required information for decisionmaking before and after the purchase of products and services, customer satisfaction will increase through the use of these networks. ${ }^{3}$

According to research undertaken by the America Marketing Association, $47 \%$ of customers reported that they use social networks to search for information in order to obtain gift ideas, and $29 \%$ of customers stated that they also purchased goods from social networks. ${ }^{4}$

Research reveals that consumers spend more time engaging in social networks rather than on other online activities such as e-mail. ${ }^{5}$ The popularity of social media among users, the attractiveness of these areas for business owners as an environment in which the client is easily accessible, the profitability of these networks for most large and small businesses, especially emerging businesses, and the success of social media and social networking sites in attracting buyers and investors suggest that social media play a very important role in the daily activities of users and the commercial processes of business owners. These advantages have led to the formation of a new business trend on these networks called social commerce. In fact, social commerce is an emerging and rapidly growing process through which online stores can connect with other stores and customers. Therefore, it is essential for businesses to implement a social commerce business model. ${ }^{6}$

A recent report by McKinsey estimates that the use of social technologies could be worth between 900 billion to 1.3 trillion U.S dollars. Furthermore, one third of consumers are influenced by social commerce. ${ }^{7}$ The use of e-commerce has numerous benefits, including increased purchasing power and the emergence of new markets for producers, cutting out middlemen, increased revenue, increased sales, quick access to information, reduction in advertising cost, and access to trans-regional 
markets. However, like any other technology, social commerce has some disadvantages, such as information security and the unknown impact on human social relations. ${ }^{8}$

Despite the increase in online shopping, a large percentage of Internet users believe that online shopping carries risk and uncertainty. The risks are greater in an online shopping environment compared to a physical shopping environment, as when shopping online, clients are unable to examine the products in person; there is a lack of tangible evidence in relation to product quality, and security and privacy concerns also arise in this context. ${ }^{9}$

Researchers have shown that buyers are more willing to buy products when other consumers have talked about the benefits of the products, rather than when they rely only on the product descriptions. Input from previous consumers comes through online rankings, voting, and recommendations. In addition, these transactions create a sense of integrity, reliability, and risk reduction in relation to a product. ${ }^{6}$

Despite the profitability of social media for most large and small businesses, unfortunately, little research has been done regarding this subject. In addition, due to the disappearance of geographical and political boundaries through social commerce, lack of interest in this context may lead to reduced income and production of domestic firms that will increase the rate of bankruptcy. So, being successful in business and daily deals requires the use of social media.

Moreover, lack of knowledge about the effective factors of social commerce adoption from the customers' perspective can become an obstacle in many business environments. In addition, given the importance of ecommerce and its continuity with economic and legal issues, a framework in which all communication patterns and problems are considered should be developed for the use of this technology.

Thus, this study sought to investigate the effect of perceived risk in terms of Internet users on the adoption of social commerce. In particular, perceived risk has been studied as a multidimensional concept, and the impact of this variable on users' buying behavior is examined with a particular focus on various aspects of risk (financial, functional, social, time, psychological, and loss of privacy). In addition, this study sought to add this dimension to the general acceptance model; thus, the Technology Acceptance Model (TAM) was selected as a reference framework, and a conceptual model consisting of various constructs of perceived risk was developed to study the basic factors influencing users' behavioral intention to purchase from social networks. Hence, organizations acquire the necessary knowledge to adopt appropriate strategies of market development 
and help government institutions and companies in more extensive implementation of e-government.

With this purpose, the current literature is examined first. Then, research methodology is expressed, and the research model and hypotheses are developed. Finally, conclusions and recommendations for future research are presented.

\section{LITERATURE REVIEW}

Today, social media is a developing phenomenon in marketing, and marketers have perceived the use of social media as a part of their marketing strategy to obtain more customers ${ }^{10}$. With the development of social networking sites in the virtual world, e-commerce and thereby social commerce have emerged, ${ }^{11,12}$ which use social media to create an environment for social interaction. ${ }^{13,14}$ The interactions through social networks and their advantages and structural features have an impact on customers' interactions and demand by increasing shared experiences through creating communities and are effective in identifying products and gathering and sharing product information that will lead to increased customer satisfaction and intention to use social commerce ${ }^{2,8,11,14}$.

Acceptance of new technologies has always been a major concern within companies and organizations. Since the acceptance of any new technology is challenging, the prerequisite of taking advantage of social commerce is its conscious acceptance. Various theories have been applied in studies on information and communication technologies (ICTs), including the theory of diffusion of innovation (DOI) that helps to identify factors affecting the adoption of an innovative information system, ${ }^{15}$ the theory of technology acceptance model (TAM) to predict and explain the willingness of users to use information technology (IT), ${ }^{16}$ the theory of technology fit (TTF) in order to understand the connection between information systems and individual performance ${ }^{17}$, the theory of planned behavior (TPB) for predicting human behavior in different situations, ${ }^{18}$ the unified theory of acceptance and use of Technology (UTAUT) to determine the behavior of the adoption and use of technology, ${ }^{19}$ and the theory of technology, organization, and environment adoption (TOE) for the acceptance of different IT products and services in the organization ${ }^{20}$ that helps to predict users' acceptance of a technology/innovation. These theories have improved users' attitudes towards ICTs and have also increased their tendency to adopt and use them ${ }^{21}$.

Among all of these theories, the TAM model is one of the most widely 
recognized models of users' acceptance and use of new technology and is more suitable for reviewing acceptance among end users ${ }^{19,22}$. According to this theory, perceived usefulness and perceived ease of use are effective regarding users' decision about new technology ${ }^{16}$.The concept of perceived risk in marketing and consumer behavior literature has been studied from different points of view. The traditional theory of decision defines this variable as consumers' possible behavioral outcomes, possibilities, and personal values ${ }^{23}$.

Research on the factors affecting social commerce acceptance revealed that perceived risk has a negative impact on social commerce acceptance ${ }^{24}$. Moreover, many researchers indicated the impact of perceived usefulness, perceived ease of use and perceived risk, ${ }^{3,6,8-9,14,23,25-33}$ subjective norms ${ }^{3}$, cultural factors $^{33-35}$, attitude, and self-efficacy ${ }^{13}$ on the acceptance of ecommerce and social commerce.

Drawing upon the theory of diffusion of innovation, Poorrangi et al. ${ }^{1}$ indicated that IT benefits, testability, top management support, resistant to change, culture, and IT complexity all affect e-commerce acceptance.Similarly, AlGhamdi et al. ${ }^{36}$ listed resistance to change, lack of clear rules in the field of social commerce, poor infrastructure, traditional ways of shopping, lack of confidence online, and lack of government regulation as the most important factors in the adoption of e-commerce. Tan et al. $^{37}$ also studied the effective factors of adoption from the B2B perspective and indicated that limited access to computers, lack of trust, lack of a culture of sharing information across the organization, and an inability to deal with rapid changes are the most important factors inhibiting the adoption of e-commerce. Rumanyika and Mashenene ${ }^{38}$ revealed that weak telecommunications infrastructure, poor security, lack of education and training, poor social and cultural readiness, and the absence of IT professionals are the most important barriers to the use of e-business in Tanzania. Moreover, Kim and Prabhakar ${ }^{39}$ indicated the positive effects of reputation, size of organization, quality of information, communities, and societies' experience on confidence in e-commerce adoption. "Social commerce is a new evolution of e-commerce that combines the commercial and social activities by deploying social technologies into e-commerce sites" Lu et al. ${ }^{40}$

In the field of social commerce, Lu et al. ${ }^{40}$ have studied social presence, trust, and social commerce purchase intention and indicated that the social presence of the web, perception of others, and social presence of interaction affect a user's trust in online sellers that consequently will increase purchase intention in social commerce. Turban et al. ${ }^{11}$ indicated that social forums and communities, recommendations and preferences, 
credits and revisions, trust, and intention to buy are the effective factors on the willingness of consumers to purchase goods. Yang and $\mathrm{Li}^{41}$ studied the effect of gender on social commerce adoption, and indicated that the pleasure of searching information affects the acceptance and intention to use social commerce among men and women. Chen et al. ${ }^{41}$ examined online impulse buying in $\mathrm{C} 2 \mathrm{C}$ social commerce and indicated the positive impact of information quality, the trait of the impulsiveness, and the number of "likes" on consumers' buying activity. In addition, Featherman et al. ${ }^{42}$ indicated that perceived risk, subjective norm, perceived usefulness, and perceived ease of use influence the intention to use an e-service in social commerce era. Sun et al. ${ }^{43}$ also indicated that customers are motivated to adopt social commerce according to their career path, motivation by others, financial profit, and technology factors. Moreover, Zhang et al. ${ }^{44}$ revealed that trust can be transferred from media and the social context to their information-gathering process.

Moreover, a social context should increase its credibility and acceptance if it attracts more users and advertisers. Hajli ${ }^{12}$ indicated that $^{2}$ consumers who use structures of social commerce to engage and create content on the Internet have more confidence and are more willing to engage in online shopping. Furthermore, Chen and Wang ${ }^{45}$ revealed the positive effect of perceived usefulness and visibility of results and the negative impact of perceived risk on confidence and intention to use social commerce. Herrando et al. ${ }^{46}$ indicated that the cognitive experience and emotional feelings related to social commerce increase user participation. Tian et al. ${ }^{47}$ have examined the effect of social information channels on consumer purchase decisions on social commerce sites and indicated that big data analytics can be successfully combined with a theoretical model to produce more robust and effective consumer purchase decisions.

The research on e-commerce and social commerce adoption is briefly shown in Table 1.

Table1. Prior research on e-commerce and social commerce

\begin{tabular}{|c|c|c|}
\hline Resource & Target & Factors \\
\hline$[47]$ & $\begin{array}{l}\text { To develop a conceptual model for } \\
\text { social commerce research }\end{array}$ & $\begin{array}{l}\text { Friends-Based Opinion; Leaders-Based Social } \\
\text { Information }\end{array}$ \\
\hline [40] & $\begin{array}{l}\text { To study the social presence, trust, } \\
\text { and social commerce purchase } \\
\text { intention }\end{array}$ & $\begin{array}{l}\text { Social Presence of Web; Perception of Others; } \\
\text { Social Presence of Interaction; Trust in Online } \\
\text { Sellers }\end{array}$ \\
\hline [41] & $\begin{array}{l}\text { To investigate online impulse buying } \\
\text { in } \mathrm{C} 2 \mathrm{C} \text { social commerce }\end{array}$ & $\begin{array}{l}\text { Information Quality of the Advertisement; Trait of } \\
\text { the Impulsiveness; Number of Likes }\end{array}$ \\
\hline
\end{tabular}




\begin{tabular}{cl}
\hline Resource & \multicolumn{1}{c}{ Target } \\
\hline$[42]$ & $\begin{array}{l}\text { To study the consumers Evaluation of } \\
\text { new e-services, new commerce } \\
\text { systems and settings, and self-service } \\
\text { technologies in the social commerce } \\
\text { era }\end{array}$ \\
[43] & $\begin{array}{l}\text { To understand the application of } \\
\text { transaction-focused social commerce } \\
\text { from the merchants'perspectives }\end{array}$ \\
{$[46]$} & $\begin{array}{l}\text { To analyze the role of passion in } \\
\text { engaging users in social commerce }\end{array}$ \\
{$[1]$} & $\begin{array}{l}\text { To study the factors affecting the } \\
\text { adoption of e-commerce }\end{array}$ \\
{$[33]$} & $\begin{array}{l}\text { To study the factors affecting the } \\
\text { adoption of e-commerce }\end{array}$ \\
{$[27]$} & $\begin{array}{l}\text { To study the product differences in } \\
\text { consumers e-commerce adoption } \\
\text { behavior } \\
\text { To study the factors affecting the } \\
\text { adoption of e-commerce }\end{array}$ \\
&
\end{tabular}

[35] To study the factors affecting the adoption of e-commerce

career path; motivation by others; financial profit; technology factors

Perceived Risk; Subjective Norm; Perceived Usefulness; Perceived Ease of Use; Intention to Use

Spread of sWOM; Enjoyment; Passion; Social Presence; Interactivity

The Benefits of Technology; Testability Capabilities; Top Management Support; Resistance to Change; Culture; The Complexity of Technology

Organizational Culture; Top Management Support; Methods of Access to the Internet; Web Portal; Availability of Technical Personnel

Perceived Usefulness, Perceived Ease of Use, Perceived Risk

Information Quality, Service Quality, System Quality, Perceived Ease of Use, Perceived Usefulness, The Confidence In the Technology, Enjoy and Benefit From The Characteristics of Technology, Attitude

Strong ICT Infrastructure; Testability of The Technology; Government Support; Reliable and Secure Online Payment Infrastructure; Staff Training and Raising Awareness of the Technology; Size of Organization; Type of Products and Services; Utility; Website Setup Costs; The Inability To transfer Services and Products; Lack of Confidence In Online Sales; Resistance to Change; Lack of Clear Rules in the Field of Social Commerce; Poor Construction of Information Technology; Old Habits And Traditional Ways of Shopping; Non-Profitable And Useful Online Payment; Lack of Adequate Products for Online Sale

[23] To study the effect of risk on the adoption and use of e-commerce

[12] To study the factors affecting the adoption of e-commerce in SMEs of Malaysia

Products and services perceived risk; perceived risk in online transactions; perceived ease of use; perceived usefulness

Attitude; self-efficacy

[29] To study the factors affecting the adoption of e-commerce in SMEs

It Security, Readiness And Willingness of Senior Managers, Perceived Usefulness, Organizational 


\begin{tabular}{|c|c|c|}
\hline Resource & Target & Factors \\
\hline & & $\begin{array}{l}\text { Readiness, Benefits of Technology, Customer } \\
\text { Needs }\end{array}$ \\
\hline [36] & $\begin{array}{l}\text { To study the factors affecting the } \\
\text { adoption of e-commerce in SMEs of } \\
\text { China }\end{array}$ & $\begin{array}{l}\text { Perceived External Readiness; Perceived Pressure } \\
\text { From The Market, Industry Readiness to Use } \\
\text { Technology; E-Government Readiness in Terms of } \\
\text { Infrastructure; Perceived Internal Preparation; The } \\
\text { Institutionalization of E-Commerce Governance; } \\
\text { Business Resources; Technology Awareness; } \\
\text { Business Type }\end{array}$ \\
\hline [2] & $\begin{array}{l}\text { To study the factors affecting the } \\
\text { acceptance of e-commerce }\end{array}$ & $\begin{array}{l}\text { Perceived Usefulness; Perceived Ease of Use; } \\
\text { External Influences and Pressures; Interaction; } \\
\text { Self-Efficacy; Facilitating Conditions; Attitudes } \\
\text { toward Technology; Subjective Norms; Behavioral } \\
\text { Control }\end{array}$ \\
\hline$[25]$ & $\begin{array}{l}\text { To study the relationship between e- } \\
\text { commerce acceptance by potential } \\
\text { buyers and their electronic experience }\end{array}$ & $\begin{array}{l}\text { Perceived Self-Efficacy; Perceived Usefulness; } \\
\text { Perceived Ease of Use; Attitudes toward } \\
\text { Technology; Intention to Buy }\end{array}$ \\
\hline [31] & $\begin{array}{l}\text { To study the effects of innovation } \\
\text { characteristics and perceived risk on } \\
\text { the adoption of e-commerce by the } \\
\text { SMEs in Bangladesh }\end{array}$ & $\begin{array}{l}\text { Perceived Technology Benefits; Flexibility of The } \\
\text { Technology; Perceived Complexity of The } \\
\text { Technology; Perceived Testability; Observability } \\
\text { of Results; Perceived Risk }\end{array}$ \\
\hline [26] & $\begin{array}{l}\text { To study the factors affecting the } \\
\text { adoption of e-commerce in SMEs of } \\
\text { Malaysia }\end{array}$ & $\begin{array}{l}\text { Organizational Readiness; External Pressure; } \\
\text { Perceived Ease of Use (The Complexity of The } \\
\text { Technology), Perceived Usefulness }\end{array}$ \\
\hline [37] & $\begin{array}{l}\text { To study the barriers of e-commerce } \\
\text { adoption among small and medium } \\
\text { enterprises in Tanzania }\end{array}$ & $\begin{array}{l}\text { Poor Telecom Infrastructure; Poor Security } \\
\text { Systems; Lack of Education And Training, Poor } \\
\text { Government Policies; Allocation of High Taxes on } \\
\text { E-Commerce Services, Poor Social And Cultural } \\
\text { Readiness; Lack of Capital; Lack of IT Specialist; } \\
\text { Sudden Changes In Technologies; Lack of } \\
\text { Communication Standards }\end{array}$ \\
\hline [34] & $\begin{array}{l}\text { To study the cultural influence on the } \\
\text { diffusion and adoption of social } \\
\text { media technologies }\end{array}$ & $\begin{array}{l}\text { Geographical Region; Business Size; Type of } \\
\text { Business; Ideas, Beliefs And Values; } \\
\text { Responsiveness To Cultural Values; Attitudes } \\
\text { Toward Trust; Familiarity With New Technology }\end{array}$ \\
\hline [28] & $\begin{array}{l}\text { To study the effects of collectivism } \\
\text { on social commerce use }\end{array}$ & $\begin{array}{l}\text { Actual Use; Intention To Use; Perceived } \\
\text { Usefulness; Perceived Ease of Use; Customer } \\
\text { Preferences; Subjective Norms; Customer Interests } \\
\text { And Concerns }\end{array}$ \\
\hline [7] & $\begin{array}{l}\text { To study the effects of social } \\
\text { comparison, social presence, and } \\
\text { enjoyment in the acceptance of social } \\
\text { shopping websites }\end{array}$ & $\begin{array}{l}\text { Factors Affecting Customer Behavior; Perceived } \\
\text { Usefulness; Perceived Pleasant Perceived } \\
\text { Usefulness; Perceived Ease of Use; Personality } \\
\text { And Social Entity }\end{array}$ \\
\hline [38] & $\begin{array}{l}\text { To study the effect of initial trust, } \\
\text { perceived risk on the adoption of e- } \\
\text { commerce }\end{array}$ & $\begin{array}{l}\text { Reputation, Size of Organization, Quality of } \\
\text { Information, Communities And Societies, } \\
\text { Experience, Confidence }\end{array}$ \\
\hline [39] & $\begin{array}{l}\text { To study the social commerce } \\
\text { adoption in China }\end{array}$ & $\begin{array}{l}\text { Perceived Usefulness; Impact of Social } \\
\text { Interactions and Associations, Searching for }\end{array}$ \\
\hline
\end{tabular}




\begin{tabular}{|c|c|c|}
\hline Resource & Target & $\begin{array}{rr}\text { Factors } \\
\end{array}$ \\
\hline$[5]$ & $\begin{array}{l}\text { To study factors affecting } \\
\text { adoption of social commerce }\end{array}$ & $\begin{array}{l}\text { Information, Saving Time } \\
\text { Orders and Delivery; Forums and Com; Unities; } \\
\text { Credits and Revisions; Trust; Perceived } \\
\text { Usefulness }\end{array}$ \\
\hline [11] & $\begin{array}{l}\text { To study the social commerce } \\
\text { structures and the willingness of } \\
\text { consumers to buy }\end{array}$ & $\begin{array}{l}\text { Social Forums and Communities; } \\
\text { Recommendations and Preferences; Credits and } \\
\text { Revisions; Trust; Intention to Buy }\end{array}$ \\
\hline$[45]$ & $\begin{array}{l}\text { To study the trust development and } \\
\text { transfer from electronic commerce to } \\
\text { social commerce }\end{array}$ & $\begin{array}{l}\text { Perceived Benefits; Perceived Risk; Perceived } \\
\text { Cost; the Visibility of Results; Confidence in } \\
\text { Electronic Commerce; Social Commerce } \\
\text { Confidence: Consistency; Intention To Use }\end{array}$ \\
\hline$[24]$ & $\begin{array}{l}\text { To study the determinants of mobile } \\
\text { commerce adoption by online } \\
\text { consumers }\end{array}$ & $\begin{array}{l}\text { Perceived Usefulness; Perceived Ease of Use; } \\
\text { Behavioral Intention to Accept Technology }\end{array}$ \\
\hline$[32]$ & $\begin{array}{l}\text { To review the current status of mobile } \\
\text { commerce adoption by } \\
\text { telecommunications companies in } \\
\text { Jordan }\end{array}$ & $\begin{array}{l}\text { External Variables; Perceived Ease of Use; } \\
\text { Perceived Usefulness; Attitude; Behavioral } \\
\text { Intention to Use The System }\end{array}$ \\
\hline$[30]$ & $\begin{array}{l}\text { To study the structure and design of } \\
\text { e-commerce and social commerce }\end{array}$ & $\begin{array}{l}\text { Usability; Information Quality; System Quality; } \\
\text { Service Quality; Perceived Usefulness }\end{array}$ \\
\hline$[44]$ & $\begin{array}{l}\text { To find the relationship between } \\
\text { customers trust to social networking } \\
\text { sites, promotional information posted } \\
\text { in this network and use of this } \\
\text { information to decide to buy }\end{array}$ & $\begin{array}{l}\text { Privacy Policies and Institutional Structures; } \\
\text { Individual Laws And Insurance; Security; Trust; } \\
\text { Publicity; Gaining A Reputation Among Users }\end{array}$ \\
\hline$[22]$ & $\begin{array}{l}\text { To study the effect of perceived risk } \\
\text { on buying behavior through the } \\
\text { Internet }\end{array}$ & $\begin{array}{l}\text { Financial Risk; Functional Risk; Time Risk; Social } \\
\text { Risk; Psychological Risk; Privacy Risk; Attitude, } \\
\text { Intention to Use, Perceived Usefulness; Perceived } \\
\text { Ease of Use }\end{array}$ \\
\hline
\end{tabular}

The research conducted on the adoption of e-commerce and social commerce have been conducted more from the perspective of business owners, and few studies have investigated the acceptance of e-commerce and social commerce from the perspective of users. In addition, few studies have been done in this area in Iran. Hence, this study examines the impact of perceived risk on the adoption of social commerce from the perspective of users using the conceptual model, developed based on the Technology Acceptance Model (TAM). Factors affecting the adoption of social commerce have been extracted by using content analysis and extensive literature review. Therefore, we have searched among the associations for ecommerce and social commerce adoption, including scientific papers, journals, databases, and various Master's and $\mathrm{PhD}$ theses/dissertations published between 2000 and 2016. At the end of the search process, a total 
of 11 factors were found that were the most closely related to the aim of this research.

\section{RESEARCH MODEL AND HYPOTHESES DEVELOPMENT}

Understanding the theoretical models that explain the acceptance and use of IT by organizations is important to facilitate a better understanding of the key IT adoption factors in the organizations of the developed and developing countries. Many studies have been conducted in the field of IT adoption, and the use of enterprise systems has shown that the TAM model is more suitable for reviewing the acceptance of end users. Since it is better that this framework be combined with other models to provide better results, different constructs of risk including financial, social, functional, time, privacy, and psychological risk were added to this model. A conceptual model is shown in Figure 1.

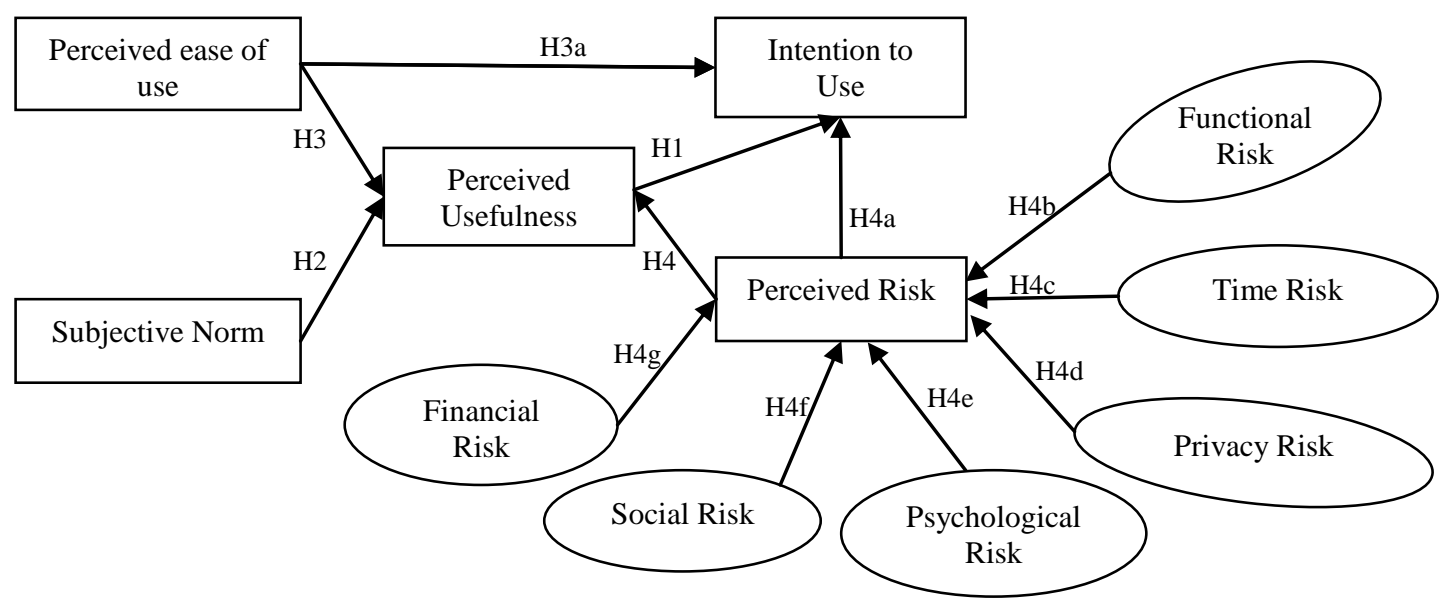

Figure 1. Research model

With regard to the literature and research model, our hypotheses are explained as follows:

\section{Perceived Usefulness}

Perceived usefulness is the extent to which any innovation or technology is considered better than others. Perceived usefulness is an important factor in adoption and has certain advantages ${ }^{19,49}$. Perceived usefulness of technology refers to the extents to which customers believe that the use of social commerce will improve the purchasing process beyond the traditional condition ${ }^{14}$. According to TAM, perceived ease of use of new technologies has a significant impact on perceived usefulness ${ }^{16}$; therefore 
we propose the following:

H1: Perceived usefulness has a positive impact on intention to use social networks.

\section{Subjective Norm}

The subjective norm is the users' belief in the importance of terms, norms, and rules for using technology ${ }^{17}$. The more impressionability social media users demonstrate and the more noticeable effect of important people on persuasion and use of the social commerce, the more the user perception of social commerce usefulness will $\mathrm{be}^{16}$. Therefore, we propose the following:

$\mathrm{H}$ 2: Subjective norm has a positive impact on perceived usefulness of social networks.

\section{Perceived Ease of Use}

Ease of use is the extent to which organizations believe that understanding, using, and learning a new technology is simple ${ }^{49,19}$, and customers believe that the use of e-commerce in cyberspace is possible without physical and mental effort ${ }^{16}$. Accordingly, if social media users feel that shopping sites and the social media platform requires less physical and mental effort and can be easily used, their perception of the usefulness of this technology is greater, and they will have higher intention to use social media; therefore, we propose the following:

H3: Perceived ease of use has a positive impact on the perceived usefulness of social networks.

H3a: Perceived ease of use has a positive impact on intention to use social networks.

\section{Perceived Risk}

Perceived risk is defined as the uncertainty of services or goods ${ }^{9}$. In social commerce, consumers can share product information with their friends and evaluate products with each other, which may lead to intrusion of privacy ${ }^{46}$. Some researchers have defined perceived risk regarding the purchase of goods in the context of e-commerce as customer perception of the uncertainty of buying a product or service through e-commerce ${ }^{27,28,30}$. Therefore, we propose the following:

H4: Perceived risk has a negative impact on the perceived usefulness of social networks. 
H4a: Perceived risk has a negative impact on the intention to use social networks.

\section{- Functional Risk}

Functional risk is the probability of product failure, lack of advertising efficiency, and ultimate lack of desired benefits due to the negative evaluation of product characteristics, dishonesty advertising, low efficiency, and poor performance of the product ${ }^{23}$. Risk refers to the factors that affect customer mentality and the possibility of using social commerce ${ }^{50}$; therefore, we propose the following:

H4b: Perceived risk of social networks is determined with its associated functional risk.

\section{- Time Risk}

The time risk is the potential harm of losing time due to a wrong purchase decision and time to search for products and purchase ${ }^{23}$. This risk refers to the customers' concerns about these subjects ${ }^{50}$; therefore, we propose the following:

H4c: Perceived risk of social networks is determined with its associated time risk.

\section{- Privacy Risk}

Privacy risk is the frustration of online shopping ${ }^{9}$. The privacy risk refers to the potential risk of losing control over personal information when user information is used without their permission ${ }^{23}$. Private information can be tracked and used on the Internet in order to share with others ${ }^{9}$. If the user's private data is collected and used without their consciousness, the use and popularity of this network will reduce ${ }^{50}$; therefore, we propose the following:

H4d: Perceived risk of social networks is determined by its associated privacy risk.

\section{- Psychological Risk}

A psychological risk refers to the inability of a customer to see the results of buying products and using other ideas. It includes the lack of testability of a product that leads to customer anxiety and apprehension while shopping ${ }^{23}$. If people can try shopping with new technology before making a decision to buy a product on the Internet, testability is present ${ }^{1,27}$, ${ }^{36}$; therefore, we propose the following:

H4e: Perceived risk of social networks is determined by its associated psychological risk.

- Social risk 
Social risk is the risk of losing one's position in social groups caused by the lack of sufficient knowledge about the usage of social networks or intentional or unintentional incorrect behavior in social networks, the influence of friends and family members, and consequently the loss of a person's social status ${ }^{23}$. Accordingly, the less users trust social media sites from which to buy products and services due to the possibility of losing their position in a social group, the more they will adopt and use social commerce; therefore, we propose the following:

H4f: Perceived risk of social networks is determined by its associated social risk.

- Financial risk

Financial risk refers to the concerns arising from the exchange of financial information and its associated risks in a virtual web environment ${ }^{48}$. In other words, financial risk refers to the possibility of losing capital paid through insecure online payment ports ${ }^{51}$, the disclosure of financial information and passwords, and fraud resulting from the lack of reliable and secure online payment infrastructure ${ }^{32}$. Moreover, financial risk includes non-profit and useless online payment methods ${ }^{36}$; therefore, we propose the following:

H4g: Perceived risk of social networks is determined by its associated social risk.

\subsection{Method: Participants and Data Collection}

The purpose of this study is to investigate the factors affecting the adoption of social commerce by Internet users based on the conceptual model developed by considering the Technology Acceptance Model (TAM) as a reference model, with emphasis on perceived usefulness and perceived risk. The basic factors influencing users' behavioral intention to buy products via social networking are studied using partial least square (PLS) and SmartPLS.2 software. An electronic standard questionnaire that previously tested data in prior research was used to gather the required information. The questionnaire was designed with two parts: the first part included some demographic information of the respondents, such as education, gender, age, and experience of shopping through social commerce. The second part included the main questions, which were based on a 5-point Likert scale ranging from strongly agree (5) to strongly disagree (1) to measure the effect of each factor. The reliability and validity of the questionnaire are examined using experts' ideas and Cranach's alpha. The Cronbach's alpha should be more than $0.6^{48}$, which was higher than 0.7 for the whole scale of the questionnaire, indicating the high reliability of the questionnaire (Table 2). 
The participants of this study included 50 active groups in Telegram, LinkedIn, and Facebook to whom the questionnaire link was sent. According to the Cochran formula for infinite population, the sample size should be 385,53 hence more than 500 questionnaires were distributed, and 170 complete useable questionnaires were received and analyzed using partial least square (PLS) and SmartPIS.2 software. According to the results, the majority of respondents (52\%) were men, $73.3 \%$ were employed, and $49.8 \%$ respondents were between 25 to 34 years old.

\section{DATA ANALYSIS}

The convergent validity, the average variance extracted (AVE), and composite reliability (CR) were used to evaluate the validity of the model. The factor loading above 0.5 is acceptable ${ }^{54}$. Based on the results, the loadings of 15 factors were less than 0.5 and were excluded from the study and the model re-run (Table 2). Those with CR values higher than 0.755 and an AVE higher than 0.556 were all acceptable. So, according to the results, the model is confirmed. Moreover, the hypotheses were tested by estimating the path coefficients and $\mathrm{R}^{2}$ value. Three values $-0.19,0.33$, and 0.67 -are considered as the criteria for quantities of weak, medium, and strong $\mathrm{R}^{2}$, respectively ${ }^{57}$. According to Table 2 , the $\mathrm{R}^{2}$ of intention to use and perceived usefulness are 0.07 and 0.20 , respectively, which are at the weak and medium levels. Moreover, the goodness of fit (GOF) of the model is used to measure the overall fitness of the model. According to Cirrone et al. 58, a GOF between 0.33 and 0.66 indicates good fitness of the model. The result of the study indicates that the GOF of the model is 0.45 , which shows a strong fit of the overall model.

Table 2. The results of the model analysis

\begin{tabular}{|c|c|c|c|c|c|}
\hline Factor & Reference & Factor Loading & AVE & $\begin{array}{l}\text { Composite } \\
\text { reliability }\end{array}$ & $\mathbf{R}^{2}$ \\
\hline Intention to Use & [23] [28] & $\begin{array}{l}0.55 \\
0.50 \\
0.60 \\
0.66 \\
0.68\end{array}$ & 0.55 & 0.71 & 0.07 \\
\hline $\begin{array}{l}\text { Perceived } \\
\text { Usefulness }\end{array}$ & [3] [14] [23] [32] & $\begin{array}{l}0.60 \\
0.63 \\
0.60 \\
0.73\end{array}$ & 0.60 & 0.72 & 0.20 \\
\hline Subjective Norm & [6] [18] & $\begin{array}{l}0.76 \\
0.61 \\
0.66\end{array}$ & 0.57 & 0.72 & \\
\hline
\end{tabular}




\begin{tabular}{|c|c|c|c|c|c|}
\hline Factor & Reference & Factor Loading & AVE & $\begin{array}{l}\text { Composite } \\
\text { reliability }\end{array}$ & $\mathbf{R}^{2}$ \\
\hline $\begin{array}{c}\text { Perceived Ease of } \\
\text { Use }\end{array}$ & $\begin{array}{c}{[23][28][16]} \\
{[32]}\end{array}$ & $\begin{array}{l}0.87 \\
0.55 \\
0.80 \\
0.66 \\
0.68\end{array}$ & 0.56 & 0.70 & \\
\hline
\end{tabular}

The result of the structural model assessment is presented in Table 3. According to the results, the subjective norm $(\beta=0.194, t=2.68)$, perceived ease of use $(\beta=0.228, t=3.84)$, and perceived risk $(\beta=0.262, t=4.062)$ have significant and positive effects on perceived usefulness. Moreover, perceived usefulness $(\beta=0.262, t=3.53)$ and perceived ease of use $(\beta=$ $0.192, t=2.070$ ) have a positive effect on intention to use. But the effect of perceived risk $(\beta=0.020, t=0.149)$ on intention to use was rejected. Therefore, hypotheses $\mathrm{H} 1, \mathrm{H} 2, \mathrm{H} 3, \mathrm{H} 3 \mathrm{a}$, and $\mathrm{H} 4$ were accepted, and hypothesis $\mathrm{H} 4 \mathrm{a}$ was rejected. In addition, the results indicated that, among all of the risk factors, all except time risk $(\beta=0.069, t=0.352)$ and psychological risk $(\beta=0.009, t=0.044)$ affect perceived risk. In general, the effects of perceived risk on intention to use were not significant, so hypotheses $\mathrm{H} 4 \mathrm{c}$ and $\mathrm{H} 4 \mathrm{e}$ were rejected, and hypotheses $\mathrm{H} 4 \mathrm{~b}, \mathrm{H} 4 \mathrm{~d}, \mathrm{H} 4 \mathrm{f}$, and $\mathrm{H} 4 \mathrm{~g}$ were supported. Based on the results, subjective norm and perceived ease of use have a positive impact on intention to use through perceived usefulness but have no effect through perceived risk. It should be mentioned that the results of the hypotheses tests are presented in Table 4 and the final model is presented in Figure 2.

Table 3. Results of hypotheses test

\begin{tabular}{|c|c|c|c|c|}
\hline Hypotheses & Relations & $t$-Value & $\begin{array}{c}\text { Path } \\
\text { Coefficient }\end{array}$ & Results \\
\hline H1 & Perceived Usefulness $\rightarrow$ Intention to Use & $3.530^{* * * *}$ & $0.262^{* * * *}$ & Accept \\
\hline $\mathrm{H} 2$ & Subjective Norm $\rightarrow$ Perceived Usefulness & $2.684^{* *}$ & $0.194^{* *}$ & Accept \\
\hline $\mathrm{H} 3$ & Perceived Ease of Use $\rightarrow$ Perceived Usefulness & $3.814^{* * *}$ & $0.228^{* * *}$ & Accept \\
\hline $\mathrm{H} 3 \mathrm{a}$ & Perceived Ease of Use $\rightarrow$ Intention to Use & $2.070^{*}$ & $0.192^{*}$ & Accept \\
\hline $\mathrm{H} 4$ & Perceived Risk $\rightarrow$ Perceived Usefulness & $4.062^{* * *}$ & $0.262^{* * *}$ & Accept \\
\hline $\mathrm{H} 4 \mathrm{a}$ & Perceived Risk $\rightarrow$ Intention to Use & $0.149^{\mathrm{x}}$ & $0.020^{\mathrm{x}}$ & Reject \\
\hline $\mathrm{H} 4 \mathrm{~b}$ & Functional Risk $\rightarrow$ Perceived Risk & $4.275^{* * *}$ & $0.644^{* * * *}$ & Accept \\
\hline $\mathrm{H} 4 \mathrm{c}$ & Time Risk $\rightarrow$ Perceived Risk & $0.035^{\mathrm{x}}$ & $0.069^{\mathrm{x}}$ & Reject \\
\hline $\mathrm{H} 4 \mathrm{~d}$ & Privacy Risk $\rightarrow$ Perceived Risk & $3.320^{* * *}$ & $0.273^{* * *}$ & Accept \\
\hline $\mathrm{H} 4 \mathrm{e}$ & Psychological Risk $\rightarrow$ Perceived Risk & $0.044^{\mathrm{x}}$ & $0.009^{\mathrm{x}}$ & Reject \\
\hline $\mathrm{H} 4 \mathrm{f}$ & Social Risk $\rightarrow$ Perceived Risk & $3.521^{* * *}$ & $0.284^{* * * *}$ & Accept \\
\hline $\mathrm{H} 4 \mathrm{~g}$ & Financial Risk $\rightarrow$ Perceived Risk & $3.526^{* * *}$ & $0.252^{* * *}$ & Accept \\
\hline
\end{tabular}

Note: $t \geq 1.96^{*} ; t \geq 2.52^{* *} ; t \geq 3.32^{* * *}$

Rejected $x$ 


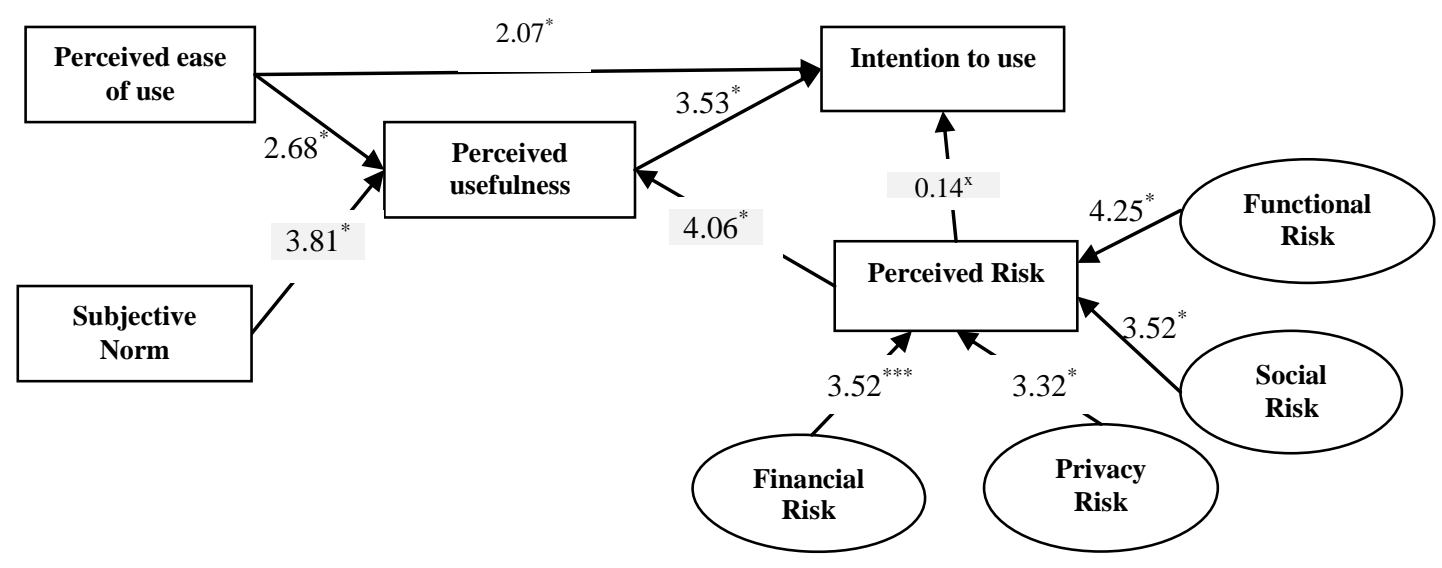

Figure 2. Results of structural model test

\section{DISCUSSION}

The rapid development of technology has caused business markets to extend beyond their geographical boundaries and has shifted the traditional marketing paradigm. Modern businesses often use online advertising and marketing, sell goods via the Internet, exchange business information electronically, and offer online auctions. Businesses relying on old methods alone are unlikely to survive ${ }^{1}$. Given the uncertain and turbulent economics, companies need to streamline their operations to reduce costs. In addition, they need inexpensive strategies to increase their competitiveness and to attract and retain more customers. Social commerce offers numerous benefits, including reduced costs, easy access to diverse products, expanded markets, decreased social costs, increased choice, and time savings as well as some disadvantages, such as privacy risk. These advantages and disadvantages have increased the need for research on social commerce adoption. Many factors influence the adoption of any new technology or innovation, and identifying and evaluating these factors can be helpful in ensuring its successful use. In this study, factors affecting the adoption of social commerce by Internet users were examined, with special attention paid to the effects of perceived usefulness and perceived risk. In particular, the study model, which includes six variables related to perceived risk (financial, functional, social, psychological, time, and privacy risk) that affect the purchase behavior of users, is expanded to obtain the necessary information for creating suitable strategies for market development. According to the results, perceived risk and psychological and time risks did not affect intention to use, which was in accordance with the findings of previous studies ${ }^{23,56}$. However, Liu and $\mathrm{Wei}^{28}$ and Azam and Quaddus ${ }^{32}$ 
found a positive impact of perceived risk on the intention to use. Furthermore, according to previous research ${ }^{8,28,29}$, subjective norm and perceived ease of use were positively associated with the intention to use. With regard to the results of the current study, when social networks simplify the process of purchasing products and services, the use and adoption of social commerce will increase. Therefore, business owners will benefit from making the online shopping process easier, providing a mechanism for sharing the shopping experience and for word-of-mouth advertising. Moreover, in accordance with the results of several studies $^{23,25,26,27,28,29}$ the effects of perceived usefulness and perceived ease of use on intention to use were approved. In addition, the effect of perceived risk on perceived usefulness was approved. Given the effect of perceived risk on perceived usefulness, the initial decision of the online trading system is fundamentally influenced by the perceived usefulness of the system. In fact, users are willing to take risks and shop online, but perceived risk influences their satisfaction and may lead to customers' mistrust and unwillingness to use social commerce if they perceive it to be unworthy. According to the results of the study, the effects of privacy risk, functional risk, social risk, and time risk on intention to use were approved in accordance with the a previous study ${ }^{32}$. Accordingly, the less risk social network users feel in getting information and ordering and receiving goods and products purchased from social media, the less financial risk there is in the purchase process of social media and less potential risk of losing time because of the wrong purchase decision they will face. The fewer searches and purchases of products customers perform, the less risk of psychological trauma will result from the unsuccessful purchase. Hence, more acceptance and use of social commerce will result.

\section{CONCLUSION AND RECOMMENDATIONS}

The use of social media has been profitable for the majority of large and small businesses. However, many studies have shown that business transfer in the context of social media and social networking is not always profitable and even leads to companies' failure and bankruptcy ${ }^{8}$. Understanding of the factors influencing the users' purchase decision helps the business to understand the reaction of clients on marketing strategies. Moreover, understanding why, where, and how customers purchase will improve marketing campaigns and will lead to a better prediction of customers' response to marketing strategies. According to the literature review of this study, few studies have investigated the acceptance of ecommerce and social commerce from the perspective of users. Moreover, the studies that have been conducted in this area (Iran) focused more on the challenges and barriers to adopt social commerce in organizations, and there 
is no research on the effective factors on social commerce adoption from the users' perspective. Hence, by investigating social commerce adoption from the perspective of social media users, this study plays an important role in the spread of adoption of new technologies. The findings of this study have practical implications for the strategic investment and design of social shopping sites. The conceptual model of this study can also be used for the adoption of other innovations. With regard to the positive impact of functional risk on willingness to accept social commerce, business owners should adopt a procedure to ensure the accuracy of advertising, increase performance, and optimize purchasing through social media. Moreover, given the positive impact of social risk, business owners should identify the risk of negative experiences by mining shared information and creating a positive feeling of shopping in the context of social media. In addition, because of the positive effect of financial risks, banks and other financial institutions must work more closely with business owners. It is also necessary to establish regulatory agencies to control the value of goods. In addition, the establishment of digital business consulting organizations and acting as a professional facilitator leads to more ease of use of social media and will increase the use of social media for purchasing goods.

Due to the recent emergence of social media, we are at the beginning step of social commerce adoption; therefore, conducting further research and providing strategies for admission is necessary. Hence, focusing more on marketing and research in the field of marketing strategies has been proposed. Moreover, suppliers and regulators need to develop strategies for market segmentation to attract more users to use social commerce. Additionally, business owners and marketing managers can develop appropriate marketing strategies and offer appropriate products by analyzing the data gathered in these networks about the relationships between customers and businesses and the similarities in their behavior. This study focused specifically on social shopping web sites. Future research should examine social commerce applications, including mobile applications and virtual reality systems to enhance our understanding of the rapid growth and potential of social commerce.

Since the economic and cultural conditions of people in developed and developing countries differ, various factors affect social commerce adoption among different countries. Therefore, it is suggested that future research examine the social commerce adoption in developed and developing countries and compare the results.

In this study, we studied some factors affecting the adoption of social commerce. Several organizational factors influence people's confidence and intention to buy, such as organizational culture and infrastructure, that can 
affect the adoption of social commerce. Therefore, future research should also examine the impact of these factors. In addition, social commerce includes various approaches such as $\mathrm{C} 2 \mathrm{C}$ and $\mathrm{B} 2 \mathrm{C}$ approaches; therefore, we suggest that future research investigate the factors influencing the adoption of social commerce and compare the results with the current findings.

\subsection{Limitations}

In this study, we studied some of the factors affecting the adoption of social commerce. Other factors influence people's confidence and intention to buy, such as organizational culture and infrastructure, that can be effective for the adoption of a social commerce. Because of the novelty of the subject, experts in this area are few. Moreover, people's familiarity with issues related to trade, social commerce, and their related risks is low, and the lack of access to some databases made the process of gathering data difficult for us.

\section{REFERENCES}

[1] M. M. Poorangi, E. W. Khin, S. Nikoonejad, and A. Kardevani, Ecommerce adoption in Malaysian Small and Medium Enterprises Practitioner Firms: A revisit on Rogers' model. Anais da Academia Brasileira de Ciências, 85(4), p1593-1604, 2013.

[2] D. Kim, Under what conditions will social commerce business models survive? Electronic Commerce Research and Applications, 12(2), p6977, 2013. http://dx.doi.org/10.1016/j.elerap.2012.12.002

[3] A. Bhattacherjee, Acceptance of e-commerce services: the case of electronic brokerages. IEEE Transactions on Systems, Man, and Cybernetics-Part A: Systems and Humans, 30(4), p411-420, 2000. http://dx.doi.org/10.1109/3468.852435

[4] H. G. Lee, and T. H. Clark, Market process reengineering through electronic market systems: Opportunities and challenges. Journal of Management Information Systems, 13(3), p113-136, 1996. http://dx.doi.org/10.1080/07421222.1996.11518136

[5] Nielsen, A. C. (2012). State of the Media-The Social Media Report 2012. Incite. Know the Customer. Retrieved 15 Jan 2014 from http://www. nielsen. com/us/en/insights/reports/2012/state-of-themedia-the-social-media-report-2012. html.N. Hajli, A research framework for social commerce adoption. Information Management \& Computer Security, 21(3), p144-154, 2013. http://dx.doi.org/10.1108/IMCS-04-2012-0024

[6] B., Lu, W., Fan and M. Zhou, Social presence, trust, and social commerce purchase intention: an empirical research. Computers in 
Human Behavior, 56, p225-237, 2016. http://dx.doi.org/10.1016/j.chb.2015.11.057

[7] J. Shen, Social comparison, social presence, and enjoyment in the acceptance of social shopping websites. Journal of Electronic Commerce Research, 13(3), p198, 2012.

[8] N. Mathur, Perceived risks towards online shopping: An empirical study of Indian customers. International Journal of Engineering Development and Research, 3 (2), p296-300, 2015.

[9] W. G. Mangold, and D. J. Faulds, Social media: The new hybrid element of the promotion mix. Journal of Business Horizons, 52, p357365, 2009. http://dx.doi.org/10.1016/j.bushor.2009.03.002

[10] Springer, Social Commerce: Marketing. Springer: Technology and Management. Springer, 2016.

[11]N. Hajli, Social commerce constructs and consumer's intention to buy. International Journal of Information Management, 35(2), p183-191, 2015. http://dx.doi.org/10.1016/j.ijinfomgt.2014.12.005

[12] A. B. Adam, J. E. B. Mat Jizat, and M. A. B. M. Nor, Internal factors within entrepreneurs that influence the acceptance and use of Social commerce among SMEs in Malaysia. DeReMa (Development Research of Management): Journal Management, 11(1), p35-45, 2016.

[13]H. E. Çelik, and V. Yilmaz, Extending the technology acceptance model for adoption of e-shopping by consumers in Turkey. Journal of Electronic Commerce Research, 12(2), p152-164, 2011.

[14]E. Rogers, Diffusion of Innovations (5th Ed.). New York: Free Press, 2003.

[15]F. D. Davis, Perceived usefulness, perceived ease of use, and user acceptance of information technology. MIS Quarterly, 13(3), p319-340, 1989. http://dx.doi.org/10.2307/249008

[16]D. L. Goodhue, and R. L. Thompson, Task-technology fit and individual performance. MIS Quarterly, 9(2), p213-236, 1995. http://dx.doi.org/10.2307/249689

[17]I. Ajzen, The theory of planned behavior. Organizational Behavior and Human Decision Processes, 50(2), p179-211, 1991.

[18] V. Venkatesh, M. G., Morris, G. B., Davis, and F. D. Davis, User acceptance of information technology: Toward a unified view. MIS Quarterly, 27(3), p425-478, 2003.

[19]L. G.Tornatzky, M. Fleischer and A. K. Chakrabarti, The Process of Technological Innovation. Lexington, MA: Lexington Books, 1990.

[20]P. Taylor, The importance of information and communication technologies (ICTs): An integration of the extant literature on ICT adoption in small and medium enterprises. International Journal of Economics, Commerce and Management, 3(5), p274-295, 2015.

[21]T. Oliveira, M., Thomas, and M. Espadanal, Assessing the determinants 
of cloud computing adoption: An analysis of the manufacturing and services sectors. Information and Management, 51(5), p497-510, 2014. http://dx.doi.org/10.1016/j.im.2014.03.006

[22] A. H. Crespo, I. R. del Bosque, and M. G. de los Salmones Sanchez, The influence of perceived risk on Internet shopping behavior: A multidimensional perspective. Journal of Risk Research, 12(2), p259277, 2009. http://dx.doi.org/10.1080/13669870802497744

[23] J. Park, D. Lee, and J. Ahn, Risk-focused e-commerce adoption model: A cross-country study. Journal of Global Information Technology Management, $\quad 7(2), \quad$ p6-30, 2004. http://dx.doi.org/10.1080/1097198X.2004.10856370

[24]L. Gitau, and D. M. Nzuki, Analysis of determinants of m-commerce adoption by online consumers. International Journal of Business, Humanities and Technology, 4 (3), p88-94, 2014.

[25]B. Hernandez, J. Jimenez, and M. José Martín, Adoption vs. acceptance of e-commerce: Two different decisions. European Journal of Marketing, 43(9/10), p1232-1245, 2009. http://dx.doi.org/10.1108/03090560910976465

[26] M. R. Shaharudin, M. W. Omar, S. J. Elias, M. Ismail, S. M. Ali, and M. I. Fadzil, Determinants of electronic commerce adoption in Malaysian SMEs' furniture industry. African Journal of Business Management, 6(10), p36-48, 2012.

[27]X. Liu, and K. K. Wei, An empirical study of product differences in consumers' E-commerce adoption behavior. Electronic Commerce Research and Applications, 2(3), p229-239, 2003.

[28] M. Noh, K. Lee, S. Kim, and G. Garrison, Effects of collectivism on actual s-commerce use and the moderating. Journal of Electronic Commerce Research, 14(3), p244-260, 2013.

[29] J. A. Mohammed, M. K., Almsafir, and A. S. M. Alnaser, The factors that affects e-commerce adoption in small and medium enterprise: A review. Australian Journal of Basic and Applied Sciences, 7(10), p406412, 2013.

[30]Z. Huang, and M. Benyoucef, From e-commerce to social commerce: A close look at design features. Electronic Commerce Research and Applications, 12(4), p246-259, 2013. http://dx.doi.org/10.1016/j.elerap.2012.12.003

[31]M. S. Azam, and M. Quaddus, Adoption of e-commerce by the SMEs in Bangladesh: The effects of innovation characteristics and perceived risk. In Proceedings of the Australian and New Zealand Marketing Academy Conference (ANZMAC), 30, 2009.

[32]W. Alrawabdeh, Environmental factors affecting mobile commerce adoption-an exploratory study on the Telecommunication firms in Jordan. International Journal of Business and Social Science, 5(8), 
p151-164, 2014.

[33]R. P. I. R. Senarathna, and H. V. A. Wickramasuriya, Organizational factors affecting e-commerce adoption in small and medium-sized enterprises. Tropical Agricultural Research, 22(2), p204-210, 2011. http://dx.doi.org/10.4038/tar.v22i2.2829

[34]L. M. Lekhanya, Cultural influence on the diffusion and adoption of social media technologies by entrepreneurs in Rural South Africa. The International Business \& Economics Research Journal (Online), 12(12), p1563-1574, 2013. http://dx.doi.org/10.19030/iber.v12i12.8250

[35]R. AlGhamdi, J., Nguyen, A., Nguyen, and S. Drew, Factors influencing e-commerce adoption by retailers in Saudi Arabia: A quantitative analysis. International Journal of Electronic Commerce Studies, 3(1), p83-100, 2012.

[36] J. Tan, K. Tyler, and A. Manica, Business-to-business adoption of eCommerce in China. Information and Management, 44(3), p332-351, 2007. http://dx.doi.org/10.1016/j.im.2007.04.001

[37] J. D. Rumanyika, and R. G. Mashenene, impediments of e-commerce adoption among small and medium enterprises in Tanzania: A review. International Journal of Information Technology and Business Managemen, 32 (1), p45-55, 2012.

[38] K. Kim and B. Prabhakar, Initial trust, perceived risk, and the adoption of internet banking. In Proceedings of the Twenty First International Conference on Information System, p.537-543, 2000.

[39]B. Lu, W. Fan, and Z M. Hou, Social presence, trust, and social commerce purchase intention: An empirical research. Computers in Human Behavior, 56, p225-237, 2016. http://dx.doi.org/10.1016/j.chb.2015.11.057

[40]J. V. Chen, B. C. Su, and A. E. Widjaja, Facebook C2C social commerce: A study of online impulse buying. Decision Support Systems, 83, p57-69, 2016. http://dx.doi.org/10.1016/j.dss.2015.12.008

[41]M. S. Featherman, and N. Hajli, Self-service technologies and eservices risks in social commerce era. Journal of Business Ethics, 139(2), p251-269, 2016.

[42]J. Sun, J. Son, and T. Chi, Adoption of transaction-focused social commerce by fashion product merchants: A study of We chat commerce in China. International Textile and Apparel Association (ITAA) Annual Conference Proceedings, 132, 2016. http://lib.dr.iastate.edu/itaa_proceedings/2016/presentations/132.

[43]X. Yang, and G. X. Li, Exploring social commerce adoption in China: A uses and gratification perspective. Paper Presented at 2014 International Conference on Management Science \& Engineering 21th Annual Conference, Helsinki, Finland, August 17-19, 2014. http://dx.doi.org/10.1109/ICMSE.2014.6930277 
[44]J. Zhang and R. K Ip, E-commerce advertising in social networking sites and implications for social commerce. Paper Presented at Pacific Asia Conference on Information Systems, Singapore, July 7-9, 2015

[45]L. Chen, and R. Wang, Trust development and transfer from electronic commerce to social commerce: An empirical investigation. American Journal of Industrial and Business Management, 6(5), p568-576, 2016. http://dx.doi.org/10.4236/ajibm.2016.65053

[46]C. Herrando, J. Jiménez-Martínez, and M. J. Martín-De Hoyos, Passion at first sight: How to engage users in social commerce contexts. Electronic Commerce Research, 16 (53), p1-20, 2016. http://dx.doi.org/10.1007/s10660-016-9251-6

[47]X. Tian, L. Liu, K. Mirkovski, and M. Li, Development of conceptual model for social commerce research through integration with big data analysis. Electronic Commerce Research, 16 (53), p1-15, 2016.

[48]H. Gangwar, H. Date, and R. Ramaswamy, Understanding determinants of cloud computing adoption using an integrated TAM-TOE model. Journal of Enterprise Information Management, 28(1), p107-130, 2015. http://dx.doi.org/10.1108/JEIM-08-2013-0065

[49] M. S. Featherman, and P. A. Pavlou, Predicting e-services adoption: A perceived risk facets perspective. International Journal of HumanComputer Studies, 59(4), p451-474, 2003. http://dx.doi.org/10.1016/S1071-5819(03)00111-3

[50] J. H. Chan-Lee, and S. Ahn, Informational quality of financial systems and economic development: An indicators approach for East Asia. Asian Development Bank Institute Working Paper, (20), 2001.

[51] J.F. Hair, W.C. Black, B.J. Babin, and R.E. Anderson, Multivariate Data Analysis (7th Ed.). Upper Saddle River, NJ: Prentice Hall, 2010.

[52]A. Hejazi, Z. Sarmad, and A. Bazargan, Research Methods in Behavioral Sciences. Tehran: Agah Publication, 2009.

[53]H. Evanschitzky, G. R. Iyer, H. Plassmann, J. Niessing, and H. Meffert, The relative strength of affective commitment in securing loyalty in service relationships. Journal of Business Research, 59(12), p12071213, 2006. http://dx.doi.org/10.1016/j.jbusres.2006.08.005

[54]D. Gefen, D. Straub, and M. C. Boudreau, Structural equation modeling and regression: Guidelines for research practice. Communications of the Association for Information Systems, 4(1), Article 7, 2000.

[55]R. P. Bagozzi, and Y. Yi, On the evaluation of structural equation models. Journal of the Academy of Marketing Science, 16(1), p74-94, 1988. http://dx.doi.org/10.1007/BF02723327

[56] W. W. Chin, The partial least squares approach to structural equation modeling. Modern Methods for Business Research, 295(2), p295-336, 1998. 
[57] G. A. P. Cirrone, S. Donadio, S. Guatelli, A. Mantero, B. Mascialino, S. Parlati, and P. A Viarengo, Goodness-of-fit statistical toolkit. IEEE Transactions on Nuclear Science, 51(5), p2056-2063, 2004. http://dx.doi.org/10.1109/TNS.2004.836124 